\title{
ЛІНГВОСТИЛІСТИКА. СОЦІОЛНГВІСТИКА
}

УДК 811. 161. 2'38

DOI: 10.31651.2226-4388-2019-26-117-123

\author{
ЛІНГВОКУЛЬТУРНИЙ КОД ЧАСУ В УКРАЇНСЬКОМУ ПОЕТИЧНОМУ \\ ДИСКУРСІ КІНЦЯ ХХ-XXI СТ. \\ А. І. Бондаренко, доктор філологічних наук, доцент, професор кафедри мовно- \\ літературної освіти та культури украӥнської мови Ніжинського державного \\ університету імені Миколи Гоголя \\ (Нізсин, Украӥна) \\ e-mail: alla_bon@ukr.net \\ ORCID: 0000-0003-4140-4733
}

У статті порушено проблему часу як лінгвокультурного феномена, у якому означено світоглядні особливості мовно-концептуальної картини світу; звернено увагу на риси вербальних контекстів, що містять ідею часу, на особливості реалізації аксіосемантики темпорального в поетичному дискурсі. Проаналізовано, зокрема, мовні й позамовні чинники репрезентації лінгвокультурного коду часу в поетичному дискурсі кіния XX-XXI cm. Реконструйовано компоненти периферійної субсистеми словообразів часу, окреслено їхню контекстуальну взаємодію із соціокультурним середовищем. Виявлено образні парадигми, побудовані на основі лексики темпоральної групи. Визначено поняттєві оператори й аксіологічні полюси конкретних оцінок, зокрема сенсорно-естетичної, утилітарної, емотивної, телеологічної та моральноетичної, продуцентами яких є буттєві метафори. Уперше запропоновано концепцію образної переінтерпретації темпорального коду в поетичному дискурсі кіния XIX-XX $\mathrm{cm}$. У $і ̈$ основі перебуває уявлення про динаміку аксіосемантичних прочесів на периферії функціональносемантичного поля темпоральності.

Ключові слова: лінгвокультурний код часу, поетичний дискурс, поняттєвий оператор оцінки, сенсорно-естетична оцінка, утилітарна оцінка, телеологічна оцінка, емотивна оцінка, морально-етична оцінка, сочіокультурні чинники переінтерпретації.

Актуальність постає з необхідності й важливості висвітлення домінантних мовносвітоглядних компонентів лінгвокультури, одним із яких $є$ код часу. Темпоральний фрагмент колективної поетичної картини світу зазнає в текстах кінця минулого й нинішньому століть метафоричної переінтерпретації, своєрідних аксіосемантичної й експресивно-стилістичної конфігурацій, розгляд яких потребує спеціальної розвідки. Поетичне мовлення - модулятор світопізнання, тому художньо-дискурсивні особливості репрезентації феномену часу є показником ставлення до сучасних соціокультурних змін.

Аналіз останніх досліджень і публікацій. Вербальні форми, у яких репрезентовано часовий бік світобуття, викликають неослабний інтерес дослідників. Розгляду лінгвокультурного коду часу в поетичному дискурсі XX ст. присвячено статті М. Калька, у яких вивчено індивідуально-авторські інтерпретації темпорального аспекту світобуття [10; 11]. У монографії Л. Кравець темпоральне як феномен лінгвокультури XX ст. проаналізовано в структурі компаративних фреймів [15]. Дослідження А. Бондаренко виявляють семантичну репрезентацію лексики темпоральної групи в поетичних текстах XX ст. як явище, спричинене лінгвосинергетичними чинниками [2; 3]. 
На увагу лінгвістів заслуговує сучасний стан інтерпретації часового коду в художньодискурсивному просторі в його зв'язках із культурними явищами кінця минулого, а також XXI ст. Таке вивчення дає можливість з'ясувати динаміку вираження лінгвокультурного феномену темпорального.

Метою дослідження $\epsilon$ аналіз мовних та позамовних механізмів репрезентації лінгвокультурного коду часу в площині поетичного дискурсу кінця XX-XXI ст., реалізований у виконанні таких завдань:

1) реконструювати периферійну субсистему словообразів часу;

2) виділити референційні площини, на які спроектовано темпоральний код;

3) визначити репертуар конкретних оцінок, продуцентами яких є словообрази часу;

4) розглянути соціокультурні чинники репрезентації лінгвокультурного коду темпорального.

Матеріали й методи дослідження. Матеріалом для аналізу слугують вербальні контексти з експліцитною семантикою часу, які належать до корпусу поезій кінця XXXXI ст. (тексти 14 письменників). Реконструкцію периферійної субсистеми словообразів часу пов'язано з семасіологічною процедурою польового моделювання. Для виявлення поняттєвих операторів оцінок застосовано компонентний аналіз. Дистрибутивним аналізом послуговуємося під час визначення основних напрямків семантизації лексики темпоральної групи в складі розгляданих образів. Семантико-стилістичний метод застосовано для окреслення конотації мовленнєвих одиниць у складі словообразів часу, а також побудови образних паралелей. Контекстологічний аналіз спрямовано в річище розгляду словесно-поняттєвих механізмів побудови й функціонування словесних образів часу. Для вивчення невербальних чинників побудови словообразів часу використано контекстуально-інтерпретаційний аналіз. Синтаксемний аналіз забезпечив виявлення синтаксемних функцій іменників темпоральної групи.

Результати дослідження та їх обговорення. У фразеосистемі національної лінгвокультури час означено в термінах ціннісних уявлень. Він постає важливим буттєвим орієнтиром, який нагадує про динаміку існування (час iде, час не жде), виконує функцію коригування поведінки (життя навчить, життя провчило, час покаже), сигналізує про нагоду для важливих дій (на часі, час пробив), належить до безперечних вартостей (заплатити життям, життям важити, подарувати життя). Уявлення про долю, смерть традиційно супроводжує поважне ставлення (доля зглянеться, іти на смерть). 3 огляду на вказані чинники вироблено мовно-світоглядний стереотип ощадливого ставлення до часу, цінування життя, усвідомлення драматичної дискретності людського існування. Тому лексика темпоральної групи в складі поетичного дискурсу XX-XXI ст., який характеризують соціокультурні зміни, $\epsilon$ вдячним матеріалом для переоцінки усталених вартостей. Такі явища накладають відбиток на аксіосемантику та стилістику вербальних контекстів із часовою семантикою.

У працях теоретиків постмодернізму, зокрема Ф. Фукуями, створено концепцію «кінця історії» [6, с. 195], яка сигналізує про втрату сподівань на суспільний прогрес. Словесно-художня версія темпорального, яку створюють постмодерністи, відображає перегляд його функціонування як буттєвої координати, а також зміну поглядів на квалітативні характеристики часу. У постмодерністських текстах час зображено як нейтралізований орієнтир, який не вказує на прогресивний поступ людства, не становить цінності. Наприклад, у семантико-стилістичній структурі вірша Патриції Килини «Між століттями» [12, с. 138] розгорнуто уявлення про своєрідну часову розгубленість, темпоральну дезорієнтованість на межі століть. Навколо ключового слова час інтегровано й лексику темпоральної групи, що становить центр декодувальної сітки твору, i мовнообразні структури, які утворюють іiі периферію. До згаданого центру належать лексеми година, вчора, сьогоднi, завтра, які перебувають зі словом час у гіпогіперонімічних зв'язках. 
Парадоксальну сутність часу вибудувано завдяки поєднанню в одному контексті суперечливих тверджень (Я вільна від часу. Я - полонена години), які не відповідають дійсному стану речей (я Цезаря знала добре; познайомлюсь із Цезарем завтра; $я$ напівнародилася $i$ теж напівумерла). Цьому сприяє використання неолексем (напівнародилася, напівумерла) та синтагм, які характеризує порушення узуальних семантико-синтаксичних зв'язків (говоріть до мене вчора; я дурніша від води). Утворення я напевне не існую, бо думаю забагато є трансформацією вислову Декарта «Я мислю, отже, існую». Анафоричний повтор займенника $я$ привертає увагу до семантики перебування людини в парадоксальному часі. Останній, за текстовою версією, не має усталеної точки відліку, як й одного напрямку руху (допускає прямий i зворотний порядок), його неможливо сприймати як буттєвий орієнтир.

На семантичному тлі текстових елементів, екстрапольованих навколо слова-стимулу час, останній перебуває в центрі таких паралелей: час - форма з різними точками відліку (я молодша від молока, старша від каменя); час - порушена послідовність подій (говоріть до мене вчора, говоріть до мене сьогодні); час - зміщення в ході історії та індивідуального буття (я Цезаря знала добре; познайомлюся з Цезарем завтра); час - неокресленість буттєво значущих подій (я напівнародилася і теж напівумерла; я напевне не існую).

Як бачимо, зазначені образні утворення вказують на амбівалентні раціональну, утилітарну й телеологічну оцінки часу, який у тексті поезії зображено доксологічним, тобто осмислюваним у контексті парадоксальних уявлень.

Аксіологізація часу відбувається завдяки перенесенню його лінгвокультурного коду на суб'єктну референційну площину. Образні парадигми з компонентом час, профільовані в поетичному дискурсі XX ст. переважно позитивно (пор.: час - трудівник, митець, гравещь та ін.) [2, с. 258], у постмодерністських текстах зазнають трансформації, негативізації. Уперше на негативну семантику буттєвих метафор кінця XX ст. звернула увагу Л. Кравець: «У поезії 80-90 років ХХ ст. посилилася скептична, негативна характеристика часу, про що свідчить залучення відповідних донорських 3он» [15, с. 334].

Темпоральне постає як діяльна сила, спрямована проти людини. Традиційну паралель час - лікар, яка перебувала на полюсі позитивної оцінки, у ХХІ ст. конкретизовано (час - хірург) та спрямовано в площину негативної телеологічної оцінки: Час, як безсилий хірург, опускає руки [14, с. 12]. Поетичне мовлення репрезентує темпоральне як діяльну силу, спрямовану на протистояння з людиною. У ХХ ст. в поетичних текстах сформовано образну паралель час - кат [24, с. 4]. Словесно-художнє світорозуміння XXI ст. відображає поглиблення зневіри в сприятливості темпорального, вербалізує його негативне сприйняття в паралелі час - убивия [20, с. 52]. М. Розумний виносить іï в сильну позицію - заголовок поетичного тексту. Цю паралель розгорнуто в контексті теонімічної семантики, пов'язаної не тільки 3 християнськими, а й загальнолюдськими цінностями в цілому: I слухає час із цікавістю вбивиі, як дихає Бог між ударами серия [16, с. 47]. На противагу паралелі, у якій темпоральне аналогізовано зі скриптором [3, с. 261], у постмодерністському дискурсі функціонує уявлення про час як спотворювача слів (пор: кохання та ніколи більше): Хай вторять з тобою те лагідне «love», щзо час перекрутить на «nevermore» [14, с. 12] (наведений приклад означують інтертекстуальні зв'язки 3 «Круком» Е. А. По). Інтегрування лексичних одиниць темпорального змісту з предметною площиною «зброя» приводить до того, що час постає в «кримінальній» буттєво-семантичній іпостасі (пор.: прищіл часу-М. Розумний [20, с. 28]).

Поетичне мовлення стає середовищем семантичної адаптації лексики на позначення індивідуального буття в площині суспільно-правових відносин, зокрема права людини на свободу, особистий вибір. У XXI ст. слово життя набуває негативної конотації морально-етичної оцінки, яку стимулює уявлення про примусовість: Бо ж ніхто не питав чи воно тобі треба народили назвали сказали жсив ... $С$ повинність життя [8, с. 39].

Словообрази часу, до яких належить лексема життя, продукують семантику буденності, їх супроводжує іронізування щодо тривалості та значущості віку людини: 
Життя велике, як батон [20, с. 62]. Лексему жизнь означують густативні асоціації, які підтримують його перебування на знижених стилістичних регістрах. Конкретнооцінну семантику цього слова зумовлює мотивація онімів Рєпніна й Полусмак відповідними загальними назвами: Якась вона, Тарасе Григоровичу, ия наша жизнь невкусна - суцільні тобі Рєпніни та Полусмакови [9, с. 120] (pina - «2. Збірн. Їстівні солодкуваті на смак корені цієї рослини» [22, VIII, с. 575]).

Переінтерпретація коду лінеарного часу відбувається завдяки адаптуванню його мовних знаків у предметній площині «непотріб». Постмодерністський дискурс демонструє перебування конотативної семантики лексеми життя на негативному полюсі сенсорноестетичної, утилітарної й телеологічної оцінок: $A$ буває, життя - як цееберка, повна стиглих вчорашніх помиїв [4, с. 54].

Якщо в модернізмі XX ст. в межах паралелі час - мистецтво життя аналогізовано 3 художньо досконалими витворами (пісня, кантата, поема), то в XXI ст. лексику на позначення буттєвого лінеарного часу спрямовано в площину деестетизації, девалоризації: Твого життя недосконалий кіч [18, с. 27]. Термін кіч, як відомо, пов'язаний з уявленням про брак смаку, недосконалість, масову культуру. Постмодерне мовомислення актуалізує в розгляданому слові семи небезпеки й негативних фізіологічних змін. Паралель життя хвороба формують метафори, побудовані на основі застарілої розмовної та діалектної лексики, що створює стилістичний ефект «привсюдності» загрози, яку спрямовує на людину час: Житте то пранщ̧и $i$ згура [5, с. 29]. Знов шахраюе доля франиувата [18, с. 18]: пранці - «Заст., розм. Сифіліс» [22, VII, с. 516].

У досліджуваний період із повсякденними, буденними реаліями аналогізовано й лексему доля (вплив естетики постмодернізму), чому сприяє контекстуальна взаємодія вказаного слова з назвами страв та напоїв, а також мовними знаками зневажливого ставлення: Доля кістлява кобіта просто хотіла готдога [19, с. 24]. Доля наша дулі варта [20, с. 119]. Нагромадженням художніх фрагментів, що належать до текстів різних епох, і вміщенням їх у структуру складнопідрядного речення з кількома підрядними із семантикою причини підкреслено брак каузальності в розумінні долі, іiі абсурність: Наша доля не прийшла, а те, щзо є, бо Парка, щзо шлюбну пряде сорочку, бо зла Юнона, суча дочка, бо соловейко не дає [14, с. 16-17]. Словесно-художнє осмислення часу опиняється в просторі гри цитатами, літературними алюзіями. Для поета XXI століття буттєві закономірності залишаються такими ж непізнаними, як і раніше.

У XX ст. в текстах поетів-екзистенціалістів функціонували образні паралелі смерть сестра та смерть - коханка [2, с. 265]. У XXI ст. шляхом оказіональної лексичної сполучуваності розширено інтимізацію поняття «смерть»: буттєвий кінець аналогізовано 3 материнською турботою: Тільки смерть клопітлива і любляча мама [8, с. 109]. Відбувається своєрідне словесно-художнє виправдання буттєвої ролі смерті, утвердження думки про іiі незначущість, байдуже ставлення до кінця снування: БУ смерті $і$ безсмертю БУ [17, с. 305]. Темпоральний фрагмент художньої картини світу відкриває можливості проекції слова смерть у площину уявлень про суспільно корисну працю: Смерть - вона як очя провідниия для неї ие просто чесна робота [7, с. 63]. У постмодерному дискурсі зазнає оцінного перекодування слово смерть, яке в національній лінгвокультурі традиційно супроводжує негативна сенсорно-естетична оцінка (пор.: чорна смерть, блідий як смерть): Смерть довгонога красуня [18, с. 46]. Люба смерте моя ясна королево [8, с. 109].

Постмодерністський підхід до слова, спрямований на зміщення лексико-стилістичних меж, спричинює адаптацію загальновживаної лексики на позначення природно-космічного часу (зима, весна, літо) в денотативній площині мовних знаків суспільного життя (пор.: ратифікація, експортувати, популіст та ін.): Творець укотре проголосить ратифікацію зими $[18$, с. 24]. I весна популіст [13, с. 51]. Наслідком постмодерністського перегляду сполучуваності поетизмів є розвиток часової семантики в площині зурочення, прокляття: Цю осінь мов наслано [14, с. 13]. Слово осінь традиційно (за незначними винятками) було виразником позитивної естетичної оцінки, що відображено в поетичному дискурсі XX ст. 
(вірші .-І. Антонича, Л. Костенко, I. Калинця та ін.). Постмодерністські тексти репрезентують перегляд естетичної конотації лексики на позначення пір року. У сучасному поетичному дискурсі функціонує деестетизований аксіосемантичний «портрет» осені: Плакса-осінь майже поряд [18, с. 47].

Для створення сполуки, яка продукує негативну утилітарну й телеологічну семантику, указуючи на хворобу, лексему осінь сполучено з медичним терміном синдром: Синдром набутої осені [14, с. 12]. Час натуралізовано, осмислено крізь семантичну призму фізіологічних відхилень. Художнє мовомислення адаптує лексему темпоральної групи день у контекстуальному середовищі, яке створюють назви небезпечних недуг: Проказа днів на тілі одкровень [20, с. 89]: проказа - «Тяжке хронічне інфекційне захворювання людини, що уражає шкіру, м'язи, гортань, внутрішні органи та нервову систему; лепра» [22, VIII, с. 194].

Аксіосемантичне та стилістичне перекодування охоплює й лексику темпоральної групи на позначення суспільно-історичного часу. Негативна оцінка суспільно-ідеологічних явищ «сензитивної епохи» (П. Сорокін) корелює 3 маркерами буденних і вульгарнонатуралістичних реалій: Це ж яке непосильне служіння на благо поспільства! - заганяти поезії прутень у дупу добі [1, с. 74]. Малюйте БАБУ голу БУ гуБАми дивиться доБА [17, c. 304]. Використання оцінного заряду прецедентних імен - ономастикону, який імплікує інформацію про час, спрямовано на створення експресії іронії: Хай живе нова доба - Ленін, Крішна й Бубаба! [23, с. 37]. Цьому сприяє розташування в низці однорідних членів речення онімічних символів комуністичної та релігійної ідеологій поряд із трансформованою назвою відомого літературного угруповання (пор.: Крішна - «божество в індуїзмі, що вшановується як одне з утілень бога Вішну» [21, с. 306]). У такий спосіб вербалізовано характеристику постмодерної епохи культурно-ідеологічної еклектики.

Висновки та перспективи дослідження. Словесні образи часу утворюють периферійну зону функціонально-семантичного поля темпоральності. Цим можна пояснити їхній зв'язок із соціокультурним середовищем, значна роль у якому належить естетиці постмодернізму, пов'язаній із переглядом усталених вартостей. Унаслідок впливу означеного контексту відбувається аксіологічна та стилістична переінтерпретація лінгвокультурного коду часу. Таке явище стає можливим унаслідок проекції темпоральної семантики на референційні площини «людина», «довкілля» та «мистецтво», денотати яких $\epsilon$ носіями негативних естетичної, утилітарної, телеологічної та морально-етичної оцінок, які супроводжує емотивна. Перспективним є дослідження в окресленому напрямку словесних образів часу з імпліцитним темпоральним компонентом.

\section{Список використаних джерел}

1. Андрухович Ю. Поезія. «БУ-БА-БУ» : вибрані твори. Львів : ЛА «Піраміда», 2008. С. 74-116.

2. Бондаренко А. Образна семантика темпоральності українських поетичних текстів XX ст. : монографія. Ніжин : Видавець Лисенко М. М., 2017. 390 с.

3. Бондаренко А. Темпоральність у поетичній мові ХХ ст. : монографія. Ніжин : Видавець Лисенко M. M., 2013. 360 c.

4. Бондар-Терещенко I. Автогеографія. Харків : Фоліо, 2006. 220 с.

5. Григорчук Т. Янголи - не дичина. Київ : Видавництво Сергія Пантюка, 2008. 128 с.

6. Енциклопедія постмодернізму ; пер. з англ. / За ред. Ч. Е. Вінквіста та В. Е. Тейлора. Київ : Видво Соломії Павличко «Основи», 2003. 503 с.

7. Жадан С. Господь симпатизує аутсайдерам. Харків: Книжковий клуб «Клуб сімейного дозвілля», 2015. 512 с.

8. Іздрик Ю. Календар любові. Львів : Видавництво Старого Лева, 2017. 425 с.

9. Ірванець О. Санітарочка Рая : вибрані вірші. К. : АБАБАГАЛАМАГА, 2015. 160 с.

10. Калько М. Етноваріант культурного коду часу у дзеркалі поетичного дискурсу шістдесятників: на матеріалі поезії В. Симоненка. Молода нація. 2006. № 3. С. 201-209.

11. Калько М. «Сьогоднішнє, вчорашнє - незмінний круг...» (репрезентація культурного коду часу в поетичному дискурсі М. Драй-Хмари). Вісник Черкаського університету. Серія «Філологічні науки». 2009. Вип. 167. С. 126-132.

12. Килина Патриція. Поезії. Поети Нью-Йоркської групи : антологія. Харків : Ранок, 2009. С. $127-146$. 
13. Короташ О. Бордель для військових : вірші. Київ : Видавництво Сергія Пантюка, 2017. 93 с.

14. Короташ О. Елегії острова Патмос : поезія. Львів : Видавничий дім «Укрпол», 2010. 104 с.

15. Кравець Л. Динаміка метафори в українській поезії XX ст. : монографія. Київ : Академія, 2012. 416 с.

16. Лазуткін Д. Червона книга : книга віршів. Чернівці : Meridian Czernowitz; Книги - XXI, 2015. 84 c.

17. Неборак В. Поезія. «Бу-Ба-Бу» : вибрані твори. Львів : ЛА «Піраміда», 2008. С. 296-346.

18. Пантюк С. Смак Бога : поезії. Київ : Видавництво Романенка «Маузер», 2009. 80 с.

19. Покальчук Ю. Інше небо : вірші. Київ : Кальварія, 2001. 104 с.

20. Розумний М. Багрянолиці. Київ : Видавництво Сергія Пантюка, 2009. 136 с.

21. Словник іншомовних слів / уклад. : С. М. Морозов, Л. М. Шкарапута. Київ : Наукова думка, 2000. $680 \mathrm{c}$.

22. Словник української мови : в 11-и томах / ред. кол.: І. К. Білодід та ін. Київ : Наукова думка, 19701980.

23. Холодний М. Усмішка Джоконди : вибране. Київ : Український письменник, 1995. 217 с.

24. Bondarenko A. Metaphors representing cratological ideas of time in Ukrainian poetic texts of the $20^{\text {th }}$ century. European Journal of Literature and Linguistics. Vienna : «East West» Association for Advanced Studies and Higher Education GmbH, 2017. № 4-2. P. 3-5.

\section{References}

1. Andrukhovych, Yu. (2008). Poeziya [Poetry]. In BU-BA-BU: vybrani tvory [BU-BA-BU: selected works] (pp. 74-116). Lviv : LA «Piramida» (in Ukr.).

2. Bondarenko, A. (2017). Obrazna semantyka temporalnosti ukrainskykh poetychnykh tekstiv XX st. [Image semantics of temporality in Ukrainian poetic texts of the $20^{\text {th }}$ c.]. Nizhyn : Vydavets Lysenko M. M. (in Ukr.).

3. Bondarenko, A. (2013). Temporalnist u poetychnii movi XX st. [Temporality in the poetic language of the $20^{\text {th }} \mathrm{c}$.]. Nizhyn : Vydavets' Lysenko M. M. (in Ukr.).

4. Bondar-Tereshchenko, I. (2006). Avtoheohrafiia [Autogeography]. Kharkiv : Folio (in Ukr.).

5. Hryhorchuk, T. (2008). Yanholy - ne dychyna [Angels aren’t fowls]. Kyiv : Vydavnytstvo Serhiia Pantiuka (in Ukr.).

6. Winquist, C. E., and Taylor, V.E., eds. (2003). Entsyklopediia postmodernizmu (per. z angl.) [Encyclopedia of postmodernism: translated from English.]. Kyiv: Vydavnytstvo Solomii Pavlychnko «Osnovy» (in Ukr.).

7. Zhadan, S. (2015). Hospod sympatyzuie autsaideram [The God likes outsiders]. Kharkiv : Knyzhkovyi klub «Klub simeinoho dozvillia» (in Ukr.).

8. Izdryk, Yu. (2017). Kalendar lyubovi [The calendar of love]. Lviv : Vydavnytstvo Staroho Leva (in Ukr.).

9. Irvanets, O. (2015). Sanitarochka Raia: vybrani virshi [Junior nurse Raia: selected poems]. Kyiv : ABABAHALAMAHA (in Ukr.).

10. Kalko, M. (2006). Etnovariant kulturnoho kodu chasu u dzerkali poetychnoho dyskursu shistdesiatnykiv: na materiali poezii V. Symonenka [Ethnovariant of the cultural code of time in the poetic discourse of the 60's based on V. Symonenko's poetry]. Moloda natsiia. 3, 201-135 (in Ukr.).

11. Kalko, M. (2009). «Sohodnishnie, vchorashnie - nezminnyi kruh...» (reprezentatsiia kulturnoho kodu chasu v poetychnomu dyskursi M. Drai-Khmary) [«Yesterday, today - unchanging circle...» (representation of the cultural code of time in poetic discourse of M. Drai-Kmara)]. Visnyk Cherkaskoho universytetu, 167, 126-132 (in Ukr.).

12. Kylyna, P. (2009). Poezii [Poems]. In Poety Niu-Iorkskoi hrupy: antolohiia (pp. 127-146). Kharkiv : Ranok (in Ukr.).

13. Korotash, O. (2017). Bordel dlia viiskovykh : virshi [Brothel for soldiers: poems]. Kyiv : Vydavnytstvo Serhiia Pantiuka (in Ukr.).

14. Korotash, O. (2010). Elehii ostrova Patmos: poeziia [Elegies of Patmos island: poetry]. Lviv : Vydavnychyi dim «Ukrpol» (in Ukr.).

15. Kravets, L. (2012). Кравець Л. Dynamika metafory v ukrainskii poezii XX st. : monohrafiia [Dynamics of metaphor in Ukrainian poetry of the $20^{\text {th }}$ c.]. Kyiv : Akademiia (in Ukr.).

16. Lazutkin, D. (2015). Chervona knyha: knyha virshiv. [Red book: book of poetry]. Chernivtsi : Meridian Czernowitz; Knyhy - XXI (in Ukr.). Ukr.).

17. Neborak, V. (2008). Poeziia [Poetry]. In Bu-Ba-Bu: selected works (pp. 296-346). Lviv : Piramida (in

18. Pantiuk, S. (2009). Smak Boha: poeziji [Taste of God: poems]. Kyiv : Vydavnytstvo Romanenka «Mauzer» (in Ukr.).

19. Pokalchuk, Yu. (2001). Inshe nebo: virshi [Other sky: poems]. Kyiv : Kalvariia (in Ukr.).

20. Rozumnyi, M. (2009). Bahrianolytsi [Crimson-faced]. Kyiv : Vydavnytstvo Serhiia Palntiuka (in Ukr.).

21. Morozov, S. M, and Shkaraputa, L. M. (eds.). (2000). Slovnyk inshomovnykh sliv [Dictionary of foreign words]. Kyiv : Naukova Dumka (in Ukr.).

22. Bilodid, I. K., et al. (1970-1980). Slovnyk ukrainskoi movy [Dictionary of Ukrainian language]. Kyiv : Naukova Dumka (in Ukr.). 
23. Kholodnyi, M. (1995). Usmishka Dzhokondy: vybrane [The smile of Gioconda: selected works]. Kyiv : Ukrainskyi pysmennyk (in Ukr.).

24. Bondarenko, A. (2017). Metaphors representing cratological ideas of time in Ukrainian poetic texts of the $20^{\text {th }}$ century. European Journal of Literature and Linguistics (4-2), 3-5.

\section{A. I. BONDARENKO. LINGUOCULTURAL CODE OF TIME IN THE UKRAINIAN POETIC DISCOURSE OF THE LATE $20^{\mathrm{TH}}-21^{\text {ST }}$ CENTURIES}

Summary. Introduction. Time is a linguocultural phenomenon which reflects the features of a specific linguistic and conceptual worldview. This article's relevance stems from the importance of studying the representation of the linguocultural code of time in poetic writing. The verbal contexts containing the idea of time have been drawing attention of scholars in semasiology, cognitive science, linguostylistics, and other linguistic disciplines. The realization of axiological semantics in poetic discourse influenced by social and cultural phenomena requires further study. This article aims at revealing the linguistic and extralinguistic factors of the ways linguocultural code is represented in the poetic discourse of the late $20^{\text {th }}-21^{\text {st }}$ centuries.

The purpose of the study is to analyze the linguistic and non-linguistic mechanisms of representation of the linguocultural code of time in the plane of poetic discourse of the late XX-XXI centuries.

Methods. The reconstruction of the peripheral subsystem of verbal images of time relies on the procedure of field modelling. Component analysis has been used to identify the conceptual operators of evaluations. Distributional analysis has been used in the semantization of temporal vocabulary within the examined images. Semantic and stylistic method has been used to outline the connotation of verbal units within temporal images, as well as to draw image parallels. Contextological analysis has been employed to reveal the verbal and conceptual mechanisms of termporal images' construction and functioning. In order to examine the non-verbal factors of temporal image construction, contextual-interpretational analysis has been used. Syntaxemic analysis has served to address the syntaxemic roles of nouns of the temporal group.

Results. Components of the peripheral subsystem of temporal images have been reconstructed, and their contextual interaction with the sociocultural environment has been outlined. The study has revealed image paradigms which rely on vocabulary of the temporal group. It has also identified conceptual operators and axiological poles of specific evaluations, including the aesthetic, utilitarian, emotive, teleological, and ethical ones produced by metaphors of time. For the first time, the study has offered a reinterpretation of the temporal code in the poetic discourse of the late $19^{\text {th }}-20^{\text {th }}$ centuries. It is based on the idea of the dynamics of axiosemantic processes at the periphery of the functional and semantic field of temporality.

Conclusions. Verbal images of time form the peripheral zone of the functional-semantic field of temporality. This can be explained by their relation to the socio-cultural environment, which plays a significant role in the aesthetics of postmodernism associated with the view of fixed values. As a result of the influence of this context, there is an axiological and stylistic reinterpretation of the linguistic and cultural code of time.

Key words: linguocultural code of time, poetic discourse, conceptual operator of evaluation, aesthetic evaluation, utilitarian evaluation, teleological evaluation, emotive evaluation, ethical evaluation, sociocultural factors of reinterpretation.

Надійшла до редакиії 08.02.19

Прийнято до друку 21.02.19 